\title{
Programy polskich partii politycznych jako material empiryczny w badaniach dyskursu politycznego ${ }^{1}$
}

Streszczenie: Programy partyjne są jedynymi dokumentami, które można uznać za całościowe wizje porządku społecznego opracowane przez partie polityczne - jedyne polityczne instytucje, które mają potencjał ich wdrożenia w przypadku zwycięskich wyborów. Są to również opracowania, które lokują partię w konkretnej, historycznej i ideowej przestrzeni, stąd powinno się je traktować w naukowym dyskursie poważnie, jako opisy pożądanej przyszłości narodu, państwa i społeczeństwa. Artykuł ma na celu omówienie problematyki programów partyjnych jako specyficznego materiału źródłowego, przedstawienie najważniejszego sposobu ich porównawczej analizy oraz zaprezentowanie doświadczeń autora z własnych badań, które obejmowały jakościową analizę treści 63 polskich programów wyborczych z lat 2001-2011. Celem artykułu jest wskazanie specyfiki polskich programów politycznych, próba wyjaśnienia ich wyjątkowości na tle innych dokumentów politycznych oraz rozważanie ich zalet/ słabości jako materiałów empirycznych w analizie polskiego dyskursu politycznego oraz ideologicznych afiliacji polskich ugrupowań partyjnych.

Słowa kluczowe: partie polityczne, programy partyjne, programy wyborcze, dyskurs polityczny, Polska

\section{Programy partyjne jako materiał źródłowy w analizach socjologicznych i politologicznych}

\footnotetext{
Iwiat polityki wytwarza olbrzymią ilość materiałów badawczych. Na każdym szczeblu ustawodawczej i wykonawczej działalności orga-

${ }^{1} \mathrm{~W}$ języku angielskim autorzy (także polscy) posługują się zamiennie terminami manifesto i programme, pisząc dość dowolnie o party programmes, electoral programmes lub electoral manifestos. Na potrzeby tego tekstu posługuję się dobrze zakorzenionymi w języku polskim formułami: programy wyborcze i programy partyjne, zdając sobie sprawę, że obie z nich nie są stuprocentowo ścisłe: niektóre programy formułowane były w omawianym okresie przez koalicje partyjne lub dotyczą wyborów prezydenckich, inne niekoniecznie publikowane były w trakcie kampanii wyborczych (patrz m.in.: Markowski, Tucker, 2010; Markowski, Cześnik, 2002).
} 
nów państwa oraz ściśle politycznej, wyborczej rywalizacji, powstają dokumenty mogące przynieść wartościowe materiały źródłowe - oficjalne publiczne dokumenty (projekty ustaw, komentarze, opinie prawne, strategiczne dokumenty i opracowania eksperckie, przekazy prasowe, briefy), zapisy debat toczonych w publicznych instytucjach (transkrypcje dyskusji w parlamentach, radach miast, komisjach różnego szczebla etc.), a także zapisy medialnych wystąpień polityków konstytuują potężną bazę danych wykorzystywanych w rozmaitych analizach.

Jak jednak pisze Ian Budge (Budge, 1994), to programy partyjne są jedynymi dokumentami, które można uznać za całościowe wizje porządku społecznego, opracowanymi przez jedyne instytucje, które w demokratycznej polityce mają potencjał ich wdrożenia w życie. Opisane w nich wizje powinno się traktować w naukowym dyskursie poważnie, jako opisy pożądanej przyszłości narodu, państwa i społeczeństwa oraz sposobu jej ucieleśnienia. Są to również dokumenty, które lokują partię polityczną w konkretnej, historycznej i ideowej przestrzeni. Formułując jej stosunek do poszczególnych grup elektoratu, stanowią podstawową autodefinicję partii jako zbiorowego aktora na scenie politycznej. W krajach o długiej tradycji demokratycznej są zasadniczymi punktami odniesienia dla innych podmiotów w dyskursie publicznym, definiującymi wspólnotę interpretacyjną lub wręcz epistemologiczną. Niezależnie od powszechnego w większości krajów demokratycznych, permanentnego i już zrytualizowanego krytycyzmu zarówno mediów, opinii publicznej, jak i świata akademickiego wobec współczesnych partii politycznych: ,są one wciąż esencją współczesnej demokracji reprezentacyjnej. Są pomostem między elektoratami a rządami. Organizują alternatywy dla wyborców przez prezentowanie programowych różnic" (Budge i in., 2006, s. xvi). Programy partyjne są tu kluczowe, jako jedyne dokumenty, zatwierdzane przez partyjne konwencje lub kongresy, będące punktem wyjścia dla działalności rządowej po zwycięskich wyborach (Budge i in., 2006, s. xvi; patrz też: Budge i in., 2001)2.

Również Tim Rapley (Rapley, 2010, s. 37-48) zwraca uwagę, że tego typu materiały są istotnymi źródłami dokumentującymi trajektorię rozmaitych dyskursów, ich modyfikacje w czasie. W ten sposób można próbować realizować badania longitudinalne, dzięki którym uda się prześledzić zmiany w agendzie tematów obecnych w dyskursie politycznym, sposobach ich konceptualizacji. Analiza treści tych dokumentów może

\footnotetext{
2 Jeżeli nie zaznaczono inaczej tłumaczenia pochodzą od autora.
} 
być elementem weryfikacji wiarygodności publikowanych w programach poglądów i koncepcji poprzez konfrontację deklaracji zapisanych w programach z działaniami podejmowanymi w trakcie rządzenia, wdrażanymi politykami - w przypadku partii wygrywających wybory oraz reakcjami na nie partii opozycyjnych: „Programy polityczne nie są, oczywiście, interesujące wyłączenie ze względu na to jak odnoszą się do działań rządu, ale także ze względu na swoje znaczenie dla wyborczego sukcesu partii, dla powstawania koalicji partii zbliżonych pod względem programowym, czy dla badań przestrzeni politycznych ograniczających wybory podejmowane przez racjonalnie działających aktorów" (Budge, 1987, s. 15).

Celem tego artykułu jest zaprezentowanie specyfiki dokumentów programowych polskich partii politycznych i kandydatów w wyborach prezydenckich. Nie aspiruje on do pełnej prezentacji naukowej dyskusji związanej z wykorzystaniem badawczym tych źródeł, odnosi się jedynie do niektórych jej wątków, podejmując kwestię statusu tych materiałów oraz rekapitulując wnioski z doświadczeń badawczych autora w zakresie ich wykorzystania w badaniach dyskursu politycznego w Polsce. Ze względu na przeglądowy, idiograficzny raczej niż analityczny, charakter opracowania, nie formułuje się tu hipotez czy pytań problemowych. W podsumowaniu zaprezentowane są jednak pewne konkluzje, próbujące wskazać dlaczego $\mathrm{w}$ analizowanym okresie dokumenty programowe miały taką formę i znaczenie. W przedsięwzięciach badawczych, które pozwoliły na opracowanie tego szkicu wzięto pod uwagę programy polityczne z lat 2001-2011. Za istotną cezurę przyjęto rok 2001, w którym podpisano Traktat nicejski decydujący de facto o rozszerzeniu Unii Europejskiej o kraje Europy Środkowo-Wschodniej, w tym Polskę. Wspólnota europejska stawała się kluczowym punktem odniesienia dla aktorów na polskiej scenie politycznej, zmieniając zasadniczo warunki politycznej rywalizacji. Wybory 2015 roku odbyły się po zakończeniu realizacji wspomnianych projektów, stąd powstałe przy tej okazji programy partyjne oraz kandydatów na prezydenta nie znalazły się w korpusie omawianych tu danych.

\section{Comparative Manifesto Project i ilościowa analiza dokumentów programowych}

Skoro programy wyborcze należą do najcenniejszych źródeł zawierających wizje porządku społecznego z perspektywy partii politycznych, czyli najważniejszych zbiorowych podmiotów życia politycznego w de- 
mokracjach parlamentarnych, badacze powinni starać się wykorzystywać je przy zastosowaniu najbardziej wyrafinowanych narzędzi metodologicznej pracy nad źródłami pisanymi.

Największy i najważniejszy projekt badawczy temu poświęcony, stawia sobie za cel gromadzenie korpusu danych umożliwiającego analizy porównawcze i longitudinalne. Ścisła kwantyfikacja treści programów, poprzez szczegółowe kodowanie i analizę ilościową, a także uwzględnienie wszystkich dokumentów, ma pozwolić zmierzyć się z zarzutami o subiektywność analiz prowadzonych w nurcie jakościowym (Budge i in., 2006, s. xvi). Zainicjowana w 1979 roku przez Iana Budge'a i Davida Robertsona z Uniwersytetu w Essex praca zespołu badawczego Manifesto Research Group (dalej: MRG), działającego w ramach konsorcjum: European Consortium for Political Research, w którym znaleźli się pochodzący z wielu krajów i uczelni badacze polityki, dała początek jednemu z największych w naukach politycznych systematycznych programów badawczych. W 1989 roku przekształcił się on w instytucję znaną dziś pod nazwą: Comparative Manifesto Project (dalej: CMP, patrz: Budge i in., 2006) afiliowaną przy Wissenschaftzentrum Berlin für Sozialforschung.

Schemat analityczny obejmuje 7 głównych sfer działalności politycznej oraz 56 kategorii kodowych. System kodowania opracowano w interdyscyplinarnej współpracy politologów, socjologów i lingwistów, próbując pokryć możliwe pełne spektrum zagadnień obecnych w dyskursie politycznym. Kolejne włączane do analiz kraje testowano pod kątem adekwatności klucza kodowego, uzupełniając go o wątki specyficzne dla scen politycznych w poszczególnych państwach.

Jak pisze Marcin Kocór, autor najpoważniejszej chyba aplikacji tej metodologii do analiz polskiej sceny politycznej: „Opierając się na kodowaniu MRG/CMP można pozycjonować partie w przestrzeni ideologicznej na dwa sposoby, odwołując się do wielowymiarowego podziału lewica-prawica. Różnice dotyczą metody określania wymiarów continuum lewica-prawica. Według pierwszego rozwiązania wymiary, na których lokowane są partie, wyznaczane są a priori, na podstawie wcześniejszych badań lub intuicji badacza. W zależności od tego podział lewica-prawica dzielony jest na kilka wymiarów. Każdy z nich określony jest przez konkretne kategorie kodowe (lewica na przykład przez podnoszenie w programach zagadnień progresywizmu podatkowego, dopuszczalności aborcji itp., a prawica przez odwołania do prywatyzacji, udziału kościoła w życiu publicznym itp.). Następnie dla poszczególnych partii zlicza się liczbę kategorii przynależnych do lewicy i prawicy. Pozycja partii na con- 
tinuum lewica-prawica określana jest najczęściej jako różnica pomiędzy sumą zagadnień lewicowych i prawicowych" (Kocór, 2005, s. 73-74)3.

$\mathrm{Na}$ stronie internetowej poświęconej CMP (https://manifestoproject. wzb.eu/), zgromadzono i udostępniono do użytku dla wszystkich zainteresowanych badaczy imponującą bazę danych składającą się (dane z 27 maja 2017 r.) z 4174 programów politycznych pochodzących z 713 wyborów, sformułowanych przez 1085 partii politycznych, z 60 krajów. Bibliografia prac naukowych korzystających z tego schematu liczy sto kilkadziesiąt pozycji.

Z perspektywy ponad trzydziestu lat trwania projektu, jego uczestnicy wskazują, że fundamentalne pytania badawcze dotyczyły identyfikacji kluczowych tematów różnicujących partie polityczne rywalizujące ze sobą w demokratycznych państwach po II wojnie światowej, a następnie longitudinalnej analizy ich obecności w dokumentach politycznych (Budge, 2006, s. xvii-xviii). W konsekwencji, można zidentyfikować pewne zestawy zagadnień charakterystyczne dla przekazu ugrupowań o konkretnym profilu ideowym, których porównywaniu poświęcone są studia podejmowane zgodnie z metodologią CMP (Budge i in., 2006, s. 116-117; Kocór, 2005, s. 70-72; Budge, 2002). Do najpoważniejszych mankamentów tego podejścia należy jednak wciąż arbitralny sposób kodowania materiału źródłowego oraz brak kontekstualizacji danych do sytuacji ideowo-politycznej w poszczególnych krajach. Te zastrzeżenia mogą być znaczące w przypadku krajów takich jak Polska, w których partie polityczne funkcjonują w warunkach demokracji nie dłużej niż trzy dekady, a scena polityczna nie jest ustabilizowana (w każdych kolejnych wyborach w parlamencie pojawiają się nowe oraz znikają z niego dotychczas obecne ugrupowania). Podsumowując swoje doświadczenia badawcze, Kocór wysoko jednak ocenia możliwości aplikacji koncepcji CMP w polskich warunkach (Kocór, 2005, s. 109), inni badacze są w tym względzie bardziej krytyczni, o czym w kolejnej części artykułu.

\section{Polskie programy partyjne - badania wlasne}

Dokumenty programowe polskich partii były materiałem źródłowym w czterech podjętych przeze mnie przedsięwzięciach badawczych ${ }^{4}$.

${ }^{3}$ Dziękuję Panu Doktorowi Marcinowi Kocórowi za udostępnienie manuskryptu swojej niepublikowanej rozprawy doktorskiej.

${ }_{4}$ Programy partyjne stanowiły punkt odniesienia dla autorów piszących o ideowych tożsamościach polskich partii, niemniej najczęściej występowały jako jedno 
W projekcie badawczym poświęconym obecności kwestii nierówności społecznych w dyskursie politycznym, programy partyjne z lat 20012007 były jednym z czterech źródeł (obok zapisów radiowych debat z udziałem parlamentarzystów oraz źródeł wywołanych - transkrypcji wywiadów indywidualnych i grupowych) stanowiących korpus danych. Efektem była publikacja książkowa (Woźniak, 2012). Kolejna inicjatywa wykorzystująca ten typ danych była kontynuacją ww. analiz mającą na celu sprawdzenie, czy sposób podejmowania problematyki nierówności w programach zmienił się w trakcie trwającego od 2008 kryzysu finansowego i gospodarczego, który temat nierówności przywrócił do agendy medialnej, politycznej i akademickiej w wielu miejscach na świecie (Woźniak, 2013). W tym celu zgromadzone na potrzeby wcześniejszego projektu dokumenty skonfrontowano z programami z wyborów $\mathrm{z}$ lat 2010 i 2011. W kolejnym przedsięwzięciu programy służyły jako źródło danych na potrzeby analizy sposobu przedstawiania problematyki zarobkowej migracji Polaków w dokumentach programowych w czasie procesu przygotowawczego do członkostwa w Unii Europejskiej oraz już po akcesji, gdy znana była skala migracji do Wielkiej Brytanii i Irlandii. Czwarty raz, programy partyjne posłużyły za źródło informacji o postawach polskich partii politycznych wobec współorganizowanych przez Polskę Mistrzostw Europy w Piłce Nożnej Euro 2012, stanowiąc część danych $w$ analizie dyskursu politycznego dotyczacego tego wydarzenia (Woźniak, 2015). W sumie na potrzeby tych projektów przeanalizowano 57 dokumentów, z wyborów parlamentarnych w lat 2001, 2005, 2007 i $2011(n=28)$, prezydenckich $\mathrm{z}$ lat 2005 i $2010(\mathrm{n}=15)$ oraz wyborów do parlamentu europejskiego $\mathrm{z}$ lat 2004 i $2009(\mathrm{n}=14)$.

Uwzględniono programy wszystkich ugrupowań, które w tym okresie przynajmniej raz miały swą parlamentarną reprezentację ${ }^{5}$ oraz wszystkich kandydatów w wyborach prezydenckich, którym udało się uzyskać poparcie wyborcze przekraczające 1 procent (patrz zestawienie poniżej) ${ }^{6}$.

z wielu źródeł, same zaś nie były poddawane szczegółowej analizie (patrz np. Kowalczyk, 2014; Antoszewski, 2012; Migalski, 2006).

${ }^{5}$ Uwzględniano także ugrupowania, które nie miały reprezentacji parlamentarnej, a które powstały na bazie partii będących w sejmie lub poprzez odłączenie się od partii grupy posłów (SdRP, Partia Demokratyczna, PJN, Libertas).

${ }^{6} \mathrm{~W}$ Polsce systematycznym gromadzeniem i publikowaniem programowych dokumentów partii politycznych zajmuje się Archiwum Partii Politycznych działające w Instytucie Studiów Politycznych Polskiej Akademii Nauk (Słodkowska, 2002; Słodkowska, Dołbakowska, 2006, 2007, 2011, 2012). Pracowniczkom Archiwum dziękuję za pomoc i udostępnienie jeszcze nieopublikowanych danych. Od niedawna 
Zestawienie analizowanych programów politycznych

\begin{tabular}{|c|c|}
\hline Wybory & Analizowane dokumenty - programy partyjne \\
\hline $\begin{array}{l}\text { Parlamentarne } \\
2001\end{array}$ & $\begin{array}{l}\text { Sojusz Lewicy Demokratycznej - Unia Pracy, Akcja Wyborcza Soli- } \\
\text { darność Prawicy, Unia Wolności, Samoobrona Rzeczypospolitej Pol- } \\
\text { skiej, Prawo i Sprawiedliwość, Polskie Stronnictwo Ludowe, Platfor- } \\
\text { ma Obywatelska, Liga Polskich Rodzin }\end{array}$ \\
\hline $\begin{array}{l}\text { Do Parlamentu } \\
\text { Europejskiego } \\
2004\end{array}$ & $\begin{array}{l}\text { PO, Samoobrona, SLD-UP, Socjaldemokracja Polska, PiS, LPR, UW, } \\
\text { PSL }\end{array}$ \\
\hline $\begin{array}{l}\text { Parlamentarne } \\
2005\end{array}$ & $\begin{array}{l}\text { LPR, Partia Demokratyczna - demokraci.pl, SdRP, PiS, SLD, PO, PSL, } \\
\text { Samoobrona }\end{array}$ \\
\hline $\begin{array}{l}\text { Prezydenckie } \\
2005\end{array}$ & $\begin{array}{l}\text { Henryka Bochniarz, Marek Borowski, Lech Kaczyński, Jarosław Kali- } \\
\text { nowski, Janusz Korwin-Mikke, Andrzej Lepper, Donald Tusk }\end{array}$ \\
\hline $\begin{array}{l}\text { Parlamentarne } \\
2007\end{array}$ & LPR, PiS, PO, PSL, Samoobrona, Lewica i Demokraci \\
\hline $\begin{array}{l}\text { Do Parlamentu } \\
\text { Europejskiego } \\
2009\end{array}$ & PSL, Samoobrona, Libertas, SLD-UP, PO, PiS \\
\hline $\begin{array}{l}\text { Prezydenckie } \\
2010\end{array}$ & $\begin{array}{l}\text { Marek Jurek, Jarosław Kaczyński, Bronisław Komorowski, Janusz } \\
\text { Korwin-Mikke, Andrzej Lepper, Grzegorz Napieralski, Andrzej Ole- } \\
\text { chowski, Waldemar Pawlak }\end{array}$ \\
\hline $\begin{array}{l}\text { Parlamentarne } \\
2011\end{array}$ & PiS, Polska Jest Najważniejsza, SLD, Ruch Palikota, PSL, PO \\
\hline
\end{tabular}

Źródło: Opracowanie własne.

W badaniach tych zastosowanie ilościowej analizy treści zgodnej z podejściem CMP okazało się niemożliwe. Jak wynika z polskich aplikacji tej metodologii (Cześnik, 2011, s. 16-17), w odniesieniu do nierówności społecznych, jedynie kategoria kodowa „sprawiedliwość społeczna”, mogła okazać się użyteczną w przypadku analiz programów partyjnych, jednak nie była obecna w programach na tyle, by stanowić zmienną w istotny sposób je różnicująca, podobnie było w przypadku pozostałych tematów. Metoda CMP okazuje się niewystarczająca w sytuacji, gdy celem badacza jest głębsza analiza konkretnej problematyki. W tym przypadku, jako że temat nierówności per se rzadko pojawiał się w programach, niezbędna była rekonstrukcja postaw ugrupowań wobec równości i nierówności społecznej poprzez analizę sposobu ujmowania w dokumentach tematyki polityki fiskalnej i społecznej, rynku pracy, wzrostu gospodarczego, kwestii klasowej, roli jednostki i wspólnoty (w tym państwa), postaw programy, w sumie 60 dokumentów z lat 1991-2011, w wersji elektronicznej są też dostępne na stronie internetowej Manifesto Research Group. 
indywidualistycznych, etc. Do tego zaś niezbędna była znajomość specyficznego kontekstu polskiej polityki oraz wiedza o działalności partii, niezbędna do weryfikacji deklaracji w odniesieniu do realnie podejmowanych działań.

Mikołaj Cześnik, który stosował metodologię CMP, wskazuje że polski sposób definiowania partii lewicowych i prawicowych jest egzotyczny z punktu widzenia akademickiego sposobu rozumienia tych pojęć, które ukształtowały się w dojrzałych i ustabilizowanych krajach demokratycznych (Cześnik, 2011, s. 20). Na podobne problemy z zastosowaniem metodologii CMP wskazywał też Radosław Markowski pisząc, iż metoda ta jest akontekstualna, nie pozwala na pogłębioną refleksję dotyczącą politycznego, społecznego i ekonomicznego kontekstu zagadnień podjętych w politycznych dokumentach (Markowski, 2002).

W celu pogłębionego rozpoznania sposobu postrzegania wybranych kwestii społecznych, a także odnoszących się do nich wątków ideologii politycznych oraz planów politycznych przeprowadzono klasyczną jakościową analizę treści programów, kodując wszelkie informacje, które łączyły się bezpośrednio lub pośrednio z analizowaną problematyką. Wnioski tu zaprezentowane płyną z doświadczeń wykorzystywania tych danych w analizach dyskursu politycznego, stąd artykuł zawiera fragmenty wcześniej przywoływanych opracowań. Wyniki tych prac rekapitulowano we wspomnianych publikacjach, poniższy fragment artykułu służy omówieniu specyfiki polskich programów partyjnych jako materiałów źródłowych.

\section{Specyfika polskich programów partyjnych}

Znaczeniu programów partii politycznych w kampaniach wyborczych poświęcona była jedna z hipotez sformułowanych na potrzeby projektu badawczego Nierówności społeczne w polskim dyskursie publicznym (Woźniak, 2012). Założenie o ich hasłowym, retorycznym raczej niż merytorycznym charakterze zostało potwierdzone w toku analiz. Poniższe uwagi odnoszą się do wszystkich omawianych dokumentów, przytaczane fragmenty uznano za reprezentatywne dla całości danych, zaś jeśli wśród analizowanych dokumentów pojawiało się opracowanie szczególnie się wyróżniające pod jakimś względem, jest to wspomniane.

Programy partyjne, przynajmniej we wziętym pod uwagę okresie, nie pozwalają na wyciagganie dalekosiężnych wniosków o ideowych opcjach 
polskich partii w zakresie polityki społecznej, sposobu postrzegania i rozwiązywania problemów społecznych, odpowiedzialności państwa. Wtórna analiza pozwala wyselekcjonować fragmenty dotyczące pośrednio tych tematów, znaczący jest również sam fakt powszechnego unikania jednoznacznych i bezpośrednich deklaracji w odniesieniu do problematyki ubóstwa, transmisji nierówności społecznych i ewentualnych sposobów przezwyciężania tych zjawisk. Wyniki tych analiz wskazują niskie zróżnicowanie postaw partii wobec tematów takich jak: nierówności, polityka podatkowa i socjalna, wskazując na znaczną konwergencję opinii faworyzujących rozwiązania liberalne. Charakterystyczna może być tu kwestia podnoszonej we wszystkich analizowanych dokumentach polityki fiskalnej. Nawet partie akceptujące progresję podatkowa, postulowały obniżanie istniejących progów, traktując obniżanie podatków jak wartość autoteliczną, w zasadzie niewymagającą dalszych uzasadnień. Wyniki te są zbieżne $\mathrm{z}$ rezultatami badań przeprowadzonych $\mathrm{w}$ innych krajach, wskazujących na podobne procesy w odniesieniu do elit politycznych, których poglądy we wspomnianych kwestiach przestają być głównymi osiami sporu politycznego (patrz np.: Bochel, Defty, 2007a; 2007b).

Cechą charakterystyczną wszystkich analizowanych dokumentów, był brak jasno sformułowanych celów wraz z opisem konkretnych działań, które mają prowadzić do ich osiagnnięcia, a także jasno opisanej hierarchii zadań, wskazania priorytetów. Brak umiejętności lub chęci zdefiniowania precyzyjnych zadań do realizacji w trakcie sprawowania władzy cechował dokumenty programowe niezależnie od ich partyjnej afiliacji.

Sposób konceptualizacji problematyki społecznej, która była głównym tematem badań oraz propozycje w tym zakresie rzadko formułowane były w odniesieniu do naukowych diagnoz. Najczęściej miały charakter hasłowy, odnosiły się do wiedzy potocznej. Dane statystyczne, najczęściej dotyczące wskaźników makroekonomicznych, prezentowane były w programach wszystkich opcji w sposób skrajnie wybiórczy. Jedynym ich celem było uzasadnienie surowej krytyki oponentów. Wyraźnie było to widać w odniesieniu do partii opozycyjnych, które w swoich programach prezentowały wyrwane z kontekstu dane statystyczne mające udowadniać nieudolność i nieefektywność partii pozostających przy władzy. W zdecydowanej większości dokumentów nie podawano źródeł przytaczanych danych, co uniemożliwiało ich weryfikację. Duża ilość danych sprawia wrażenie poważnych eksperckich opracowań, chociaż niektóre stwierdzenia są całkowicie niezrozumiałe. W jednym z programów Platformy Obywatelskiej czytamy np.: ,Skala dysproporcji docho- 
dowych sięga dziś w Polsce, po czterech latach rządów lewicy, poziomu nienotowanego nigdy wcześniej, tj. 1:300, co prowadzi do tego, że obywatele uważają realne dysproporcje za wyjątkowo niesprawiedliwe" (Słodkowska, Dołbakowska, 2007, s. 174). Trudno powiedzieć, czym jest przytoczona w tym zdaniu proporcja, ani czym różnią się dysproporcje dochodowe od realnych dysproporcji dochodowych. W cytowanym dokumencie, w jednym przypadku pojawiają się dane podparte autorytetem naukowym: „Co trzeci z żyjących poniżej minimum egzystencji to dziecko, które nie skończyło 14 roku życia. Województwa świętokrzyskie, warmińsko-mazurskie, podkarpackie, podlaskie i lubuskie należy, wedle prof. Warzywody-Kruszyńskiej, uznać w całości za enklawy dziecięcej biedy" (Słodkowska, Dołbakowska, 2007, s. 174). Są to informacje nieścisłe lub nieprawdziwe, niestaranności w dokumencie jest zresztą więcej, przekręcono nawet nazwę instytutu badawczego „Centrum Analiz Społeczno-Ekonomicznych” współtworzonego przez Leszka Balcerowicza i dostarczającego ekspertyzy gospodarcze. Podobnie niejasne sformułowania pojawiają się w innych miejscach tego opracowania, np. „Elementarny brak dostosowania struktury lecznictwa do współczesnych metod leczenia (np. zawał obecnie leczy się 3 dni - kiedyś 3 tygodnie, operacja pęcherzyka żółciowego wymaga 2 a nie 7 dni hospitalizacji itp.)" (Słodkowska, Dołbakowska, 2007, s. 174).

Nieliczne odwołania do badań naukowych są wybiórcze, często wyrwane z kontekstu, jak przytoczony przykład odwołania do badań ubóstwa Warzywody-Kruszyńskiej w programie wyborczym Donalda Tuska. Opracowaniem, które wymieniane jest jako źródło danych jest Diagnoza społeczna, najczęściej z odwołaniem do nazwiska Janusza Czapińskiego, jednego z jej współautorów.

Manipulacje w programach mogą dotyczyć właściwie wszelkich ich elementów, nie tylko danych statystycznych. W programie Platformy Obywatelskiej z 2007 roku, zatytułowanym Polska zasługuje na cud gospodarczy, partia odwołuje się do nauczania Jana Pawła II jako źródła inspiracji: „«Zdolność człowieka do inicjatywy i przedsiębiorczości stanowi źródło bogactwa społecznego, zaś wolny rynek jest najbardziej skutecznym narzędziem wykorzystywania zasobów i zaspokajania potrzeb». Te słowa Jana Pawła II pochodzące z encykliki Centesimus Annus (IV, 32-34), dobrze wyrażają nasze przekonanie o wartości twórczego i aktywnego wysiłku człowieka w procesie gospodarczym. Nie na darmo Platforma postawiła sobie za cel uwolnić energię Polaków" (Słodkowska, Dołbakowska, 2011, s. 173-260). Cytat ten nie jest jednak dokładnym 
przytoczeniem słów papieża, a kompilacją fragmentów zmontowanych w sposób korzystny dla autorów, kluczowy jego fragment in extenso brzmi w sposób zmieniający jego ideowe przesłanie: „Wydaje się, że zarówno wewnątrz poszczególnych narodów, jak i w relacjach międzynarodowych wolny rynek jest najbardziej skutecznym narzędziem wykorzystania zasobów i zaspokajania potrzeb. Dotyczy to jednak tylko tych potrzeb, za których zaspokojenie można zapłacić, to jest które dysponują siłą nabywczą, i tych zasobów, które »nadają się do sprzedania«, czyli mogą uzyskać odpowiednią cenę. Istnieją jednak liczne ludzkie potrzeby, które nie mają dostępu do rynku. W imię sprawiedliwości i prawdy nie wolno dopuścić do tego, aby podstawowe ludzkie potrzeby pozostały nie zaspokojone i do wyniszczenia z tego powodu ludzkich istnień" (Jan Paweł II, 1991, s. 34).

Poza bardzo nielicznymi przypadkami, brak w programach odwołań do autorytetów naukowych i ich wiedzy eksperckiej. Jest to o tyle zaskakujące, że naukowcy i badacze z wielu dziedzin są członkami wszystkich polskich partii politycznych, często pełniąc w nich eksponowane i wpływowe funkcje, pojawiając się na dobrych miejscach na listach wyborczych, wchodzą w skład komitetów poparcia. Najwyraźniej ich rolą jest raczej legitymizacja kandydatur naukowym cenzusem i prestiżem swojej profesji niż eksperckie doradztwo. Ich kompetencje na potrzeby opracowywania programów nie były wykorzystywane lub też nie możemy o tym wnioskować ze względu na fakt, że niewiele dokumentów jest podpisanych jakimikolwiek nazwiskami. W wyborach prezydenckich, najczęściej wyłącznie sami kandydaci sygnują programy. W przypadku wyborów parlamentarnych dokument najczęściej podpisany jest nazwą partii politycznej, ewentualnie z adnotacją podobną jak pod zatytułowanym Nowoczesna, solidarna, bezpieczna Polska dokumentem programowym Prawa i Sprawiedliwości z 2011 roku: „Przygotował zespół parlamentarzystów i ekspertów pod przewodnictwem Jarosława Kaczyńskiego, prezesa PiS” (Prawo i Sprawiedliwość, 2011, s. 2).

Sojusz Lewicy Demokratycznej prezentował się w materiałach programowych jako partia odwołująca się do tradycji lewicowych, posługująca się hasłami społecznej sprawiedliwości, jednak w jej przekazie ideowym było dużo chaosu i często sprzecznych ze sobą deklaracji. $\mathrm{Z}$ jednej strony fakt narastania nierówności społecznych traktowano jako społecznie negatywne zjawisko, z drugiej jednak nie brano pod uwagę faktu, jakie konsekwencje dla niego może mieć przeprowadzona podczas rządów SLD liberalizacja kodeksu pracy zwiększająca znacząco odsetek 
osób samozatrudnionych. Podobnie jak w przypadku partii prawicowych i liberalnych, traktowano niskie podatki jako wartość autoteliczna, aksjomat, który może przynieść wyłącznie korzyści. Obniżka podatku CIT uznawana była w 2005 roku za kluczowe osiagnnięcie gabinetu SLD z lat 2001-2005. Brak było zarówno w programach SLD, jak i SdPL oraz lewicowych kandydatów na prezydenta jakichkolwiek odwołań do uniwersalistycznych świadczeń społecznych, tradycyjnie kojarzonych z postulatami lewicowymi, redystrybucja poprzez system podatkowy uznawana była za konieczna, jednocześnie formułowano konieczność dalszego obniżania obciążeń fiskalnych.

Programy stanowią swoistą wizytówkę, pozwalają się ideowo zdefiniować oraz określić potencjalne kategorie wyborców, do których kierowany jest przekaz oraz określić te grupy społeczne, w imieniu których partia lub kandydat występuje. Większość przeanalizowanych programów zawierała hasła i odwołania do wszystkich grup społecznych, przekonywała o uniwersalności swojego przekazu, co jest charakterystyczne dla partii typu catch all, kierujących swą ofertę polityczną do maksymalnie szerokiego spektrum elektoratu. Partie unikały w programach jasnych deklaracji ideowych i autodefinicji, jednak w odniesieniu do kwestii społecznych, analiza programów wskazywała na ich ewidentnie klasowy charakter.

Jako partię tego typu zwykło się postrzegać PSL, definiowane jako ugrupowanie chłopskie lub ludowe. Rzeczywiście problematyka wsi i rolnictwa jest w materiałach programowych tej partii podnoszona najczęściej, a partia definiuje się jako reprezentant interesów Polaków zamieszkujących wieś. Jednak nie tylko PSL zwracał się w swoim programie bezpośrednio do konkretnej klasy. Podobnie w przypadku programów Unii Wolności oraz Platformy Obywatelskiej, a także kandydatów tych ugrupowań w wyborach prezydenckich, jasno formułowano deklaracje o konieczności wspierania polskiej klasy średniej oraz przedsiębiorców, jako kluczowej z punktu widzenia państwa kategorii. Pojawiały się w nich wprost stwierdzenia o uprzywilejowaniu pracowników najemnych w porównaniu z sytuacją przedsiębiorców, o konieczności liberalizacji kodeksu pracy i systemowego wspierania klasy posiadaczy. Wrażenie szczególnego chaosu można odnieść zapoznając się z materiałami programowymi Unii Wolności, w której przekaz kierowany był explicite do klasy średniej, przy czym zakres pojęciowy tej kategorii pozostaje niezdefiniowany. Brak klarownej definicji, kogo zalicza się do hołubionej w programie grupy, ułatwia poszerzanie potencjalnej bazy elektoratu, może również bu- 
dzić aspiracje do członkostwa w tak, zdaniem autorów programu, ważnej kategorii. Rozbudowę klasy średniej traktowano jako receptę na minimalizowanie społecznych nierówności oraz ich skutków. Jednocześnie zasadnicze wątki programowe dotyczyły wspierania przedsiębiorców, także poprzez zmniejszanie fiskalizmu. Sprzeczność interesów między przedsiębiorcami, w których interesie jest obniżanie podatków, a członkami klasy średniej pracującymi w instytucjach budżetowych - nauczycielami, akademikami, urzędnikami administracji centralnej i samorządowej nie jest wyartykułowana, wewnętrzne zróżnicowanie klasy średniej jest całkowicie zlekceważone. Ekonomiczny sukces niezdefiniowanej i amorficznej klasy średniej w programie PO traktowano jako najważniejszy motywacyjny stymulant mogący wzmocnić aktywność społeczną i biznesową społeczeństwa. Co ciekawe, politycy dawnej Unii Wolności, wraz z niektórymi politykami SLD występujący w wyborach 2005 roku jako „Demokraci.pl” definiowali się jako ugrupowanie antyestablishmentowe, koncentrując się na krytyce alienujących się elit politycznych, mimo iż trudno znaleźć bardziej wpływowe środowisko polityczne w okresie pierwszych 15 lat istnienia III Rzeczpospolitej niż środowisko UW i Unii Demokratycznej.

W przypadku Platformy Obywatelskiej zaskakuje brak koherencji w przekazie i standardzie produkowanych materiałów programowych. W roku 2005 ukazał się podpisany przez Jana Rokitę i Stefana Kawalca Plan rzq̨dzenia 2005-2009, wyjątkowy w polskim kontekście dokument, będący spójna, technokratyczną i opartą o diagnozy zespołu wielu - wymienionych z nazwiska - akademickich ekspertów propozycją programu politycznego ${ }^{7}$. Jest to oferta konsekwentnie neoliberalna, składająca się z opracowań dotyczących 37 obszarów funkcjonowania państwa i gospodarki ułożonych w trzy bloki tematyczne: „Rząd uczciwy, skuteczny i tani”, „Wzrost gospodarczy i praca dla Polaków w Polsce” oraz „Państwo jako dostarczyciel dóbr publicznych", stawiającą na pierwszym planie konieczność poprawy gospodarczych wskaźników, podejmującą szczegółowe kwestie związane także z technologią rządzenia i wprowadzania zmian.

7 Z punktu widzenia analiz obecności problematyki nierówności w polskich programach partyjnych, symptomatycznym jest, że jedyne odwołanie do nierówności w tym dokumencie nie dotyczy Polski, mimo że rok 2005, gdy opracowanie powstawało, był apogeum ich wzrostu w okresie transformacji. W 263-stronnicowym dokumencie kwestia ta poruszona jest raz, autorzy piszą, że minimalizacja nierówności globalnych jest istotna w kontekście walki z terroryzmem i że Polska powinna aktywniej angażować się w pomoc rozwojową (Rokita, Kawalec, 2005, s. 261). 
W tym samym czasie cytowany już powyżej program polityczny kandydata PO na prezydenta Donalda Tuska był chaotycznym, a nawet niestarannym pod względem edycyjno-informacyjnym zbiorem postulatów o charakterze zarówno liberalnym, jak i socjalnym. Podwójne wybory 2005 roku, po wycofaniu się Włodzimierza Cimoszewicza z wyborów prezydenckich, uważa się czasem za kres „,podziału postkomunistycznego", by odwołać się do znanej kategorii Mirosławy Grabowskiej (2004). Program PiS w mniejszym stopniu odwoływał się do kwestii ekonomicznych, gdyż w prognozowanym i zapowiadanym koalicyjnym rządzie PO-PiS, to ta pierwsza partia miała objąć ministerstwa związane z gospodarką i finansami. Partia postkomunistyczna utraciła trzy czwarte poparcia, które pozwoliło jej wygrać wybory w 2001 roku, zaś głównymi konkurentami stały się partie i politycy mający korzenie w opozycji demokratycznej okresu PRL. Podział na „Polskę solidarną” i „Polskę liberalną", który w trakcie podwójnej kampanii wyborczej roku 2005 - prezydenckiej i parlamentarnej - organizował medialny spór polityczny, nie ma odzwierciedlenia w programach wyborczych, co może potwierdzać tezę Ewy Nalewajko o czysto taktycznym i instrumentalnym potraktowaniu kwestii podziału na Polskę solidarną i liberalną (Nalewajko, 2007, s. 16-17).

\section{Konkluzje}

Większość analizowanych materiałów programowych pełni de facto funkcję bardziej rozbudowanych ulotek wyborczych niż programowych dokumentów politycznych. Może to świadczyć o braku wiary w możliwość zastosowania sformułowanych w tego typu dokumentach postulatów w praktyce rządzenia, ale też o braku nadziei na merytoryczną debatę polityczną nad treścią dokumentów programowych, być może wynikającym ze słabości polskiego dyskursu politycznego i braku zainteresowania mediów polemikami programowymi.

Wydaje się, że polska demokracja charakteryzuje się niską wiarą elit politycznych w sensowność i ważność tworzenia tego typu dokumentów w sposób merytoryczny, biorąc odpowiedzialność za treści w nich zawarte. Ten sposób komunikacji między politykami a wyborcami jest najwyraźniej niedoceniany. Zapewne kluczowa jest tu polska kultura polityczna w formie ukształtowanej po 1989 roku, jednak można też wskazać inne źródła takiego stanu rzeczy, m.in. konstrukcję legislacji dotyczą- 
cej kampanii wyborczych oraz sposób finansowania partii politycznych - z budżetu państwa, proporcjonalnie do ich sukcesu we wcześniejszych wyborach. Sposób przeznaczenia tych środków na wydatki związane z kampanią wyborczą jest określony ustawowo. Dotychczasowe dyskusje dotyczące zmiany zasad wydawania tych środków, np. ograniczenia możliwości finansowania reklam wyborczych i kampanii prowadzonej za pośrednictwem różnych mediów (spoty telewizyjne i internetowe, bannery, billboardy i cityboardy), pozostają bezkonkluzywne.

Stało się normą, że partie polityczne największą część środków inwestują w kampanie medialne oraz polityczne ,iwenty" w rodzaju konwencji wyborczych, które uznaje się powszechnie za najskuteczniejsze oraz w największym stopniu przyciagające zainteresowanie mass-mediów. Trudno powiedzieć, by była to sytuacja niekorzystna dla tych ostatnich - szczególnie media elektroniczne są beneficjentami wydatków na reklamy. Zapewne można to uznać za jeden z aspektów komercjalizacji, i w konsekwencji - tabloidyzacji obecnego w mediach dyskursu politycznego w Polsce. Także media papierowe, w tym te opiniotwórcze, w sytuacji mocno spolaryzowanej ideowo sceny (tak politycznej, jak i medialnej) zainteresowane są częściej raportowaniem lub nawet podsycaniem konfliktów personalnych, niż analizą i merytoryczną weryfikacją politycznych deklaracji formułowanych w programach wyborczych.

Z badań nad specyfiką sceny politycznej w krajach postkomunistycznych wynika jasno, że bezkrytyczne aplikowanie ram analitycznych wypracowanych w studiach nad zachodnimi demokracjami może tworzyć artefakty badawcze. Realne działania partii deklarujących się jako lewicowe w warunkach postkomunistycznej transformacji cechował np. znaczniejszy konserwatyzm fiskalny, niż w przypadku partii prawicowych. Natalia Letki i Margit Tavits, podsumowując swe badania wskazują również, że: ,traktowanie poważnie deklaracji (stated policy positions) zamieszczonych $\mathrm{w}$ dokumentach programowych czy prezentowanych w przekazach medialnych, bez ich weryfikacji - analizą realnych działań politycznych, nie daje prawdziwego obrazu podziałów ideowych na scenie politycznej: pozycjonowania partii politycznych na podstawie deklaracji a ich rzeczywistych zachowań niekoniecznie przynoszą tożsame wyniki. Jest to sprzeczne ze standardową wiedzą płynącą ze studiów nad zachodnimi demokracjami, rodzi wątpliwości co do równoprawnego traktowania deklaracji i zachowań. Badania wykorzystujące deklaracje do analizy polityki partyjnej dotyczącej działań politycznych, tworzenia koalicji i innych podobnych aktywności, mogą być mylące, gdy realnie 
wdrażane polityki (policies) nie odzwierciedlają tychże" (Tavits, Letki, 2009, s. 567).

\section{Bibliografia}

Antoszewski A. (2012), System polityczny RP, Warszawa.

Bochel H., Defty A. (2007a), MPs'Attitudes to Welfare: A New Consensus?, „Journal of Social Policy", vol. 36 (1).

Bochel H., Defty A. (2007b), Welfare Policy under New Labour: Views from Inside Westminster, Policy Press, Bristol.

Budge I. (1994), A new spatial theory of party competition, „British Journal of Political Science", vol. 24 (4).

Budge I. (1987), The internal analysis of electoral programmes, w: Ideology, strategy and party change: spatial analyses of post-war elections programmes in 19 democracies, red. I. Budge, D. Robertson, D. Hearl, Cambridge University Press, Cambridge.

Budge I., Robertson D., Hearl D. (1987), Ideology, strategy and party change: spatial analyses of post-war elections programmes in 19 democracies, Cambridge University Press, Cambridge.

Budge I., Klingemann H. D., Volkens A., Bara J., Tanenbaum E. (2001), Mapping Policy Preferences: Estimates for Parties, Electors, and Governments 19451998, Oxford University Press, Oxford.

Budge I. (2002), Mapping policy preferences: 21 years of the comparative manifestos project, „European Political Science”, vol. 1 (3).

Budge I., Klingemann H. D., Volkens A., Bara J., McDonald M. (2006), Mapping Policy Preferences: Estimates for Parties, Electors, and Governments in Eastern Europe, European Union and OECD 1990-2003, Oxford University Press, Oxford.

Cześnik M. (2011), Zawartość programów wyborczych polskich partii politycznych - zastosowanie metody MRG do ilościowej analizy treści, w: Wybory 2007. Partie i ich programy, red. I. Słodkowska, M. Dołbakowska, ISP PAN, Warszawa.

Grabowska M. (2004), Podziat postkomunistyczny. Spoleczne podstawy polityki w Polsce po 1989 roku, Wydawnictwo Naukowe Scholar, Warszawa.

Jan Paweł II (1991), Encyklika Centesimus Annus, http://www.nauczaniejp2.pl/dokumenty/wyswietl/id/24, 23.11.2015.

Kocór M. (2007), Dynamika polskiej sceny politycznej. Analiza przeptywów poparcia politycznego, niepublikowana praca doktorska, Instytut Socjologii, Uniwersytet Jagielloński, Kraków.

Kowalczyk K. (2014), Typologia polskich partii politycznych wedtug kryterium programowego, „Środkowoeuropejskie Studia Polityczne”, vol. 1. 
Markowski R. (2002), Propozycja Manifesto Research Group: metoda, wyniki, problem - komentarz, w: System partyjny i zachowania wyborcze. Dekada polskich doświadczeń, red. R. Markowski, ISP PAN, Warszawa.

Markowski R., Tucker J. A. (2010), Euroscepticism and the Emergence of Political Parties in Poland, „Party Politics”, vol. 16 (4).

Markowski R., Cześnik M. (2002), Polski system partyjny: dekada zmian instytucjonalnych $i$ ich konsekwencje, w: System partyjny i zachowania wyborcze. Dekada polskich doświadczeń, red. R. Markowski, ISP PAN, Warszawa.

Migalski M. (2006), Polskie ugrupowania parlamentarne na tle diady lewica-prawica, w: Polski system partyjny, red. M. Migalski, W. Wojtasik, M. Mazur, PWN, Warszawa.

Nalewajko W. (2007), Wybory prezydenckie 2005: ciagłość czy zmiana instytucji, w: Wybory prezydenckie 2005. Programy kandydatów, red. I. Słodkowska, M. Dołbakowska, ISP PAN, Warszawa.

Prawo i Sprawiedliwość (2011), Nowoczesna, solidarna, bezpieczna Polska. Program Prawa i Sprawiedliwości, Warszawa.

Rapley T. (2010), Analiza konwersacji, dyskursu i dokumentów, PWN, Warszawa.

Rokita J., Kawalec S. (red.) (2005), Państwo dla obywateli. Plan rzadzenia 2005-2009, Instytut Państwa i Administracji, Warszawa.

Słodkowska I. (red.) (2002), Wybory 2001. Partie i ich programy, ISP PAN, Warszawa.

Słodkowska I., Dołbakowska M. (red.) (2006), Wybory 2005. Partie i ich programy, ISP PAN, Warszawa.

Słodkowska I., Dołbakowska M. (red.) (2007), Wybory prezydenckie 2005. Programy kandydatów, ISP PAN, Warszawa.

Słodkowska I., Dołbakowska M. (red.) (2011), Wybory 2007. Partie i ich programy, ISP PAN, Warszawa.

Słodkowska I., Dołbakowska M. (red.) (2012), Wybory prezydenckie 2010. Programy kandydatów, ISP PAN, Warszawa.

Słodkowska I., Dołbakowska M. (red.) (2013), Wybory 2011. Partie i ich programy, ISP PAN, Warszawa.

Tavits M., Letki N. (2009), When Left is Right: Party Ideology and Policy in PostCommunist Europe, „American Political Science Review”, vol. 103 (4).

Woźniak W. (2012), Nierówności społeczne w polskim dyskursie politycznym, Wydawnictwo Naukowe Scholar, Warszawa.

Woźniak W. (2013), Polarization and political agenda. Inequalities in manifestos of political parties in Poland, referat na konferencję ,Social Policy and Economic Development, European Social Policy Analysis Network", Uniwersytet Ekonomiczny w Poznaniu, Poznań, 5-7 września.

Woźniak W. (2014), Post-accession migration as perceived in political discourse in Poland. Analysis of the party manifestos from a period of 2001-2011, referat na konferencję „In the frame? Public and Political Discourses of Migration”, 
Power, Discourse \& Society Research Cluster, University of Limerick, Irlandia, 24-25 kwietnia.

Woźniak W. (2015), Euro 2012 i Kraków 2022. Polskie elity polityczne wobec Wielkich Imprez Sportowych, „Przegląd Socjologii Jakościowej”, vol. XI, nr 2.

\title{
The manifestos of political parties in Poland as empirical material in studies on political discourse
}

\begin{abstract}
Summary
Party manifestos are the only political documents which can be perceived as holistic visions of the social order formulated by political parties - the only political bodies eligible to implement them after winning elections. These are documents which place a given party in a concrete, historical and ideological context, therefore they should be seriously considered in academic discourse as descriptions of an envisioned and desired future of the nation, state and society. The paper aims to approach party manifestos as a specific kind of source data, present the most typical method of comparative analysis, and share the author's own experiences from several research attempts which embraced a qualitative analysis of party manifestos from 2001-2011 (altogether 57 documents). The paper points at the peculiarities of Polish parties' manifestos and attempts to explain their specific characteristics in comparison to other political documents, and discuss their advantages and weaknesses as a source data for the analysis of Polish political discourse and ideological stances of Polish parties.
\end{abstract}

Key words: political parties, party manifestos, electoral manifestos, political discourse, Poland 